\title{
Kronik bel-boyun ağrılı hastaya yaklaşım ve değerlendirme yöntemleri
}

\section{Approach and evaluation methods for patients with chronic back and neck pain}

\author{
Suna Akın Takmaz
}

S. B. Ankara Ĕ̆itim ve Araştırma Hastanesi Anesteziyoloji-Reanimasyon ve Algoloji Kliniği, Ankara

Kronik bel ve boyun ağrıları, biyolojik, psikolojik ve sosyokültürel faktörler arasında karmaşık etkileşimlerle karakterize bir hastalıktır. Çok boyutlu doğası gereği, kronik bel ve boyun ağrılarının etkili tanı ve tedavisi çok eksenli bir yaklaşım gerektirir. Kapsamlı bir sorgulama ve fizik muayeneyi takiben, gerekli durumlarda laboratuvar tetkikleri ve görüntüleme yöntemlerinden yararlanılarak, ağrının nedeninin ortaya konulması önemlidir. Ancak, organik patolojinin belirlenmesine yönelik yapılan biyomedikal yaklaşımların yanı sıra potansiyel sosyal, duygusal, bilişsel, çevresel ve davranışsal faktörlerin ortaya çıkarılmasına yönelik olarak, standart değerlendirme araçlarından da yararlanılmalıdır. Bu makalede, kronik bel ve boyun ağrılı hastaların değerlendirilmesindeki temel bileşenlerin vurgulanması amaçlanmıştır.

Anahtar sözcülkler: kronik bel ağrısı; kronik boyun ağrısı; değerlendirme
Chronic pain is a disorder characterized by complex interactions between biological, psychological and sociocultural factors. Due to multidimensional nature of chronic back and neck pain, efficacious assessment, and treatment requires a comprehensive, multiaxial approach. It's important to present the cause of pain by using laboratory and imaging methods when necessary, following detailed questioning and examination. Standard evaluation methods should be used to reveal potential social, emotional, cognitive, environmental and behavioral factors, besides biomedical approach to detect organic pathologies. In this article, we aimed to emphasize the main components in evaluation of patients with chronic back and neck pain.

Key words: chronic back pain; chronic neck pain; assessment

tüm insana odaklı biyo-psikososyal yaklaşım modeli benimsenmelidir. Kapsamlı bir sorgulama ve fizik muayeneyi takiben, gerekli durumlarda laboratuvar tetkikleri ve görüntüleme yöntemlerinden yararlanılarak, ağrının nedeninin ortaya konulması son derece önemlidir. Organik patolojinin miktarı veya türü ile ağrı yoğunluğu arasında birebir ilişki olmayıp, kronik ağrı deneyimi sayısız biyomedikal, psikososyal (örn; hastanın inançları, beklentileri ve ruh hali) ve davranışsal faktörler tarafindan şekillenmektedir. Bu nedenle, organik patolojinin belirlenmesine yönelik yapılan biyomedikal yaklaşımlara ilave olarak, potansiyel sosyal, duygusal, bilişsel, çevresel ve davranışsal faktörlerin ortaya çıkarılmasına yönelik, standart değerlendirme araçlarından da yararlanılmalıdır. Bu makalede, kronik bel ve boyun ağrılı hastaların değerlendirilmesindeki temel bileşenler irdelenerek vurgulanmaya çalışılmıştır.

- Illetişim adresi: Doç. Dr. Suna Akın Takmaz, Meksika Cad. 2449. Sok. Kardelen Sitesi A Blok. No. 7/35 Ümitköy, Ankara Tel: 0505 - 4514117 e-posta: satakmaz@gmail.com

- Geliş tarihi: 20 Șubat 2017 Kabul tarihi: 20 Șubat 2017 


\section{KLINIK DEĞERLENDIRME}

Kronik bel ve boyun ağrıları, mekanik bozukluktan, yaşamı tehdit eden ciddi neoplazik hastalıklara varan birçok nedenle karşımıza çıkabilmektedir (Tablo 1). $\mathrm{Bu}$ hastalarda, klinik değerlendirme ile ağrının biyomedikal, fonksiyonel ve psikososyal boyutları ortaya konulmalı, hastalar özürlülük (disability) ya da engelliliklerine (handicap) göre sınıflandırılmalı ve ilgili disiplinler ile birlikte ele alınarak tedavisi planlanmalıdır. Bu anlamda "klinik öykü" değerlendirmenin ilk ve temel basamağıdır.

\section{Öykü}

Ayrıntılı bir öykü, ağrının olası nedeni ve mekanizmasının anlaşıması, ciddi bir durum belirtisi olan "kırmızı bayrakların" veya uzun süreli engellilik ve iş kaybına neden olan psikososyal faktörlerin tanımlandığı "diğer renklerdeki bayrakların” ortaya çıkarılması açısından büyük önem taşır (Tablo 2). Kırmızı bayraklar olarak adlandırılan ciddi durumlar, her ne kadar sık görülmeseler de, mortalite ve morbidite nedeni olmaları nedeniyle iyi analiz edilmeli, öyküye yönelik ayrıntılı fizik muayeneyi takiben, gerekli olduğunda ileri tetkikler erkenden yapılmalıdır. Literatürde altın standart olarak tanımlanmış tek bir kırmızı bayrak listesi yoktur. Bel ve boyun ağrıları için kırmızı bayraklar Tablo 3 ve Tablo 4'te gösterilmiştir. ${ }^{[5,6]}$

\section{Tıbbi geçmiş öyküsü ve sistemlerin gözden geçirilmesi}

Mesleki durum, travma öyküsü, geçirilmiş ameliyatlar bilinmelidir. Ağrı nedeni olabilecek bilinen bir hastalık varlığı (osteoporoz, osteoartrit, disk bozuklukları) ya da bu açıdan risk faktörlerinin olup olmadığı açığa çıkarılmalıdır. Yaş, obezite, mesleki faktörler, postüral problemler yanı sıra malignite, enfeksiyon gibi ciddi durumlar açısından risk faktörleri gözden geçirilmelidir. Örneğin immünosupresyon, intravenöz ilaç kullanımı veya yeni geçirilmiş bir cerrahi müdahale varlığı, enfeksiyon açısından önemli bir risk faktörü olarak değerlendirilmelidir.

Ağrıya eşlik eden semptomlar sorgulanarak, ayrıntılı bir sistemik değerlendirme yapılmalı ve ağrının sistemik organik nedenleri olup olmadığı araştırılmalıdır. $\mathrm{Bu}$ amaçla; ateş, terleme ve titreme (enfeksiyon); kilo kaybı ve kötü iştah (enfeksiyon veya kanser); yorgunluk, depresif belirtiler ve baş ağrısı (çok faktörlü mekanik ağrı); yutma sırasında boyun ağrısının kötüleşmesi (özofageal bozukluklar); iştahsızlık, bulantı, kusma ve barsak disfonksiyonu veya dışkı değişikliği (gastrointestinal rahatsızlıklar); idrar yolu semptomları ve yan ağrısı (üriner sistem rahatsızlıkları, nefrolitiazis); öksürük, nefes darlığı ve inspirasyon sırasında ağıı (pulmoner bozukluklar); vajinal kanama veya menstrüel siklus problemleri (pelvik bozukluklar) gibi ağrıya eşlik eden semptomların olup olmadığı belirlenmelidir.

\section{Mevcut ağrının değerlendirilmesi}

Ağrının başlama şekli, yeri, şiddeti, yayılımı, süresi, postür ve aktivite ile ilişkisi, gece ve gündüz seyri, ağrıyı azaltan ve arttıran faktörler, uygulanan tedaviler, kullanmakta olduğu ilaçlar saptanmalıdır. Sabah sertliği, uyuşma, parestezi, güçsüzlük, üriner retansiyon ve inkontinans gibi ağrıya eşlik eden semptomlar sorgulanmalıdır. Ayrıntılı bir öyküyle, ağrının kaynağına dair (somatik, radiküler, nörojenik, inflamatuvar, visseral, psikojenik) önemli ipuçları elde edilebilir. Nöropatik ağrılar tipik olarak ateşlenme, yanma, elektrik çarpması, bıçak saplanması şeklinde tarif edilirken, mekanik ağrılar genellikle zonklama veya acıma şeklinde tanımlanır. Nöropatik ağrıya sıklıkla uyuşma, parestezi veya dizestezi eşlik eder. Yürümekle artan ve oturmayı gerektiren ağrılar spinal stenozu akla getirmelidir. İstirahatte azalmayan veya artan ağrı olarak tanımlanan istirahat ağrısında, neoplazik hastalıklar veya enfeksiyon düşünülmelidir. Ateş, iştahsızlık ve kilo kaybı varlığında, enfeksiyon ve tüberkülozdan şüphelenilmedir. Ayrıca, kilo kaybı malignitenin önemli bir belirtisi olarak karşımıza çıkabilir. Omurga kaynaklı tümör veya spondiloartropatilerde ağrı yatmakla artarken, mekanik ağrılarda tipik olarak hareketle, ayakta durmak ve uzun süreli oturmakla artar ve yatmakla azalır. Kronik bel ve boyun ağrılarının en sık nedeni olan mekanik kaynaklı ağrıların ayırıcı tanısında, öyküden elde edilen bilgiler önemli bir yol göstericidir (Şekil 1). ${ }^{[7]}$

\section{Psikososyal değerlendirme}

Kronik bel ve boyun ağrılı hastalarda psikososyal faktörlerin, uzun dönem sakatlık ve geç işe dönüşte önemli rolü olduğu bilinmektedir. ${ }^{[8]}$ Bu nedenle, psikososyal faktörler özellikle başlangıç klinik değerlendirme sırasında ve tedavi süreci boyunca, düzenli olarak dikkate alınmalıdır. ${ }^{[9]}$ Psikososyal faktörlerin değerlendirilmesinde, bu amaç için oluşturulmuş bayrak tanımlama sisteminden yararlanılması önerilmektedir (Tablo 2).

Duyusal boyut: KBBA, genellikle olumsuz duygularla ilişkilidir. Kronik ağrısı olan hastaların \%50'sinde eşlik eden depresif bozukluklar ve anksiyete olduğu bilinmektedir. ${ }^{[10]}$ Bu hastalarda, eşzamanlı depresif belirtilerin artan özürlülük ve artmış ağrı deneyimiyle ilişkili olduğu gösterilmiştir. Bu ve diğer olumsuz duyguların farkında olunması ve bunlarla baş edilmesi, tedavide başarılı olunması açısından önemlidir.

Kognitif boyut: Bilişsel durumlar, ağrı algısını ve ağrı ile ilişkili özürlülüğü etkileyen bir diğer önemli boyuttur. Özellikle ağrının aşırı abartılı olarak değerlendirilmesi veya hastanın ağrısının kalıcı olacağı, iş ve 
Tablo 1. Kronik bel ve boyun ağrısı nedenleri

\begin{tabular}{|c|c|}
\hline \multirow[t]{9}{*}{ Mekanik nedenler (\%80-90) } & İdiyopatik \\
\hline & Disk dejenerasyonu \\
\hline & Paraspinal kas kaynaklı \\
\hline & Faset eklem kaynaklı \\
\hline & Vertebra kırıkları \\
\hline & Spondilozis, spondilolistezis \\
\hline & İnstabilite \\
\hline & Spinal deformiteler (kifoz, skolyoz vb.) \\
\hline & Postlaminektomi sendromu \\
\hline \multirow[t]{6}{*}{ Nörojenik nedenler (\%5-15) } & Disk hernisi \\
\hline & Spinal stenoz \\
\hline & Osteofitik sinir kökü basısı \\
\hline & Annüler yırtık, kimyasal sinir kökü irritasyonu \\
\hline & Başarısız bel-boyun cerrahisi sendromu \\
\hline & Enfeksiyon (Herpes Zoster) \\
\hline \multirow[t]{4}{*}{ Mekanik olmayan patolojiler (\%1-2) } & Malignite (primer veya metastatik tümörler) \\
\hline & Enfeksiyon (spondilodiskit, osteomiyelit, abse) \\
\hline & İnflamatuvar spondiloartropatiler (RA, ankilozan spondilit, psöriatik artrit) \\
\hline & Paget hastalığı \\
\hline \multirow[t]{8}{*}{ Diğer nedenler (\%2-4) } & Fibromiyalji \\
\hline & Konnektif doku hastalıkları \\
\hline & Somatoform bozukluklar \\
\hline & Abdominal aort anevrizması \\
\hline & Gastrointestinal nedenler \\
\hline & Pelvik nedenler \\
\hline & Retroperitoneal nedenler \\
\hline & Servikal vasküler ve visseral nedenler \\
\hline
\end{tabular}

Tablo 2. Klinik değerlendirmede kullanılan kırmızı ve diğer bayrak tanımlama sistemleri

\begin{tabular}{|c|c|c|}
\hline Bayrak & Doğası & Örnek \\
\hline Kırmızı & Ciddi patoloji bulguları & - Tümör, kauda ekina sendromu, kırık \\
\hline Sarı & $\begin{array}{l}\text { İnançlar, değerler ve yargılar } \\
\text { Duygusal cevaplar } \\
\text { Ağrı davranışı (ağrı kopyalama } \\
\text { davranışlarını da içerir) }\end{array}$ & $\begin{array}{l}\text { - Ağrı hakkında yanlış inançlar; bulguların kontrol edilemeyeceği veya kötüleşmeye eğilimli } \\
\text { olduğuna inanma } \\
\text { - Mental hastalık tanı kriterlerine uymayan üzüntüler } \\
\text { - Endişe, korku, kaygı } \\
\text { - Ağrı ve yeniden yaralanma korkusu nedeniyle aktivitelerden kaçınma } \\
\text { - Pasif tedavi modalitelerine aşırı güvenme (sıcak uygulaması, soğuk uygulaması, } \\
\text { analjezikler vb.) }\end{array}$ \\
\hline Turuncu & Psikiyatrik semptomlar & - Klinik depresyon, kişilik problemi \\
\hline Mavi & $\begin{array}{l}\text { Sağlık ve iş arasındaki ilişki } \\
\text { hakkındaki algılar }\end{array}$ & $\begin{array}{l}\text { - İşin ağır olduğu ve muhtemelen yeni bir yaralanmaya yol açacağına inanma } \\
\text { - İş̧yerindeki üstlerinin ve/veya çalışma arkadaşlarından destek görmediğine inanma }\end{array}$ \\
\hline Siyah & Sistemsel veya özel engeller & $\begin{array}{l}\text { - İ̧se dönüşe engel olan kanuni seçenekler } \\
\text { - Yaralanma ve tazminat talepleri hakkında sigorta ile anlaşmazlık } \\
\text { - Aşırı endişeli aile veya sağlık ekibi } \\
\text { - Ağır iş yükü ve görevi modifikasyonunda çok kısıtlı seçenek olması }\end{array}$ \\
\hline
\end{tabular}


Tablo 3. Bel ağrısı için kırmızı bayraklar

\begin{tabular}{ll}
\hline Klasik kırmızı bayraklar & Yeni kırmızı bayraklar \\
\hline Yaş $>50$ & Azalmış mobilite \\
Açıklanamayan kilo kaybı & Belirsiz non-spesifik alt ektremite bulguları \\
Kanser & Şerit tarzında gövde ağrısı \\
Gece ağrısı & \\
Ateş & \\
Eğer şeklinde anestezi & \\
Illerleyici nörolojik defisit & \\
İdrar yapmakta güçsüzlük & \\
Sistemik kortikosteroid kullanımı & \\
İntravenöz ilaç kullanımı & \\
\hline Erken HY'den alınmıştır. ${ }^{[5]}$ &
\end{tabular}

Tablo 4. Boyun ağrısıyla ilişkili kırmızı bayraklar

\begin{tabular}{|c|c|c|}
\hline Kırmızı bayrak & Olası durumlar & iliş̧kili işaret ve semptomlar \\
\hline $\begin{array}{l}\text { Travma (düşme, motorlu araç kazası, kamçı } \\
\text { yaralanma gibi) }\end{array}$ & $\begin{array}{l}\text { Vertebral kırıklar, spinal kord hasarı, bağ } \\
\text { parçalanması }\end{array}$ & $\begin{array}{l}\text { Bilinç kaybı veya dalgalanması, kognitif } \\
\text { defisitler, travmatik beyin hasarı, başağrısı, } \\
\text { nörolojik semptomlar }\end{array}$ \\
\hline $\begin{array}{l}\text { Romatoid artrit, Down sendromu, } \\
\text { spondiloartropati }\end{array}$ & Atlantoaksiyel subluksasyon & $\begin{array}{l}\text { Kolay yorulma, yürüyüş anormallikleri, kısıtlı } \\
\text { boyun mobilitesi, tortikollis, spastisite, duyusal } \\
\text { defisitler, üst motor nöron bulguları }\end{array}$ \\
\hline Yapısal semptomlar & $\begin{array}{l}\text { Metastazlar, enfeksiyöz durum, sistemik } \\
\text { romatolojik hastalık }\end{array}$ & $\begin{array}{l}\text { Kilo kaybı, açıklanamayan ateş, anoreksi, } \\
\text { ailesel veya kişisel malign neoplazma öyküsü, } \\
\text { yaygın eklem ağrısı ve sertliği, anormal } \\
\text { laboratuvar test sonuçları }\end{array}$ \\
\hline
\end{tabular}

Enfeksiyöz semptomlar

Üst motor nöron lezyonları

Yaş $<20$ yıl

Birlikte göğüs ağrısı, diaforezis veya nefes darlığı

Yaş $>50$ yıl
Epidural abse, spondilodiskit, menenjit

Spinal kord kompresyonu, demiyelinizan hastalıklar

Konjenital anomaliler (servikal spina bifida, Scheuermann hastalığı), enfeksiyon gibi madde yanlış kullanımı ile ilişkili durumlar

Miyokard iskemisi veya enfarktüs

Metastazlar, vertebra kırı̆̆ı, karotis veya vertebral arter disseksiyonu/kanaması
Ateş, boyun sertliği, fotofobi, beyaz küre hücre sayısı artışı

Hoffmann işareti, hiperrefleksi, Babinski işareti, spastisite, inkontinans, seksüel disfonksiyon

Konjenital anomaliler: doğum lekeleri, cilt yüzeyinde çıkıntılar, saç kümeleri, aile öyküsü, sistemik hastalıklar (diyabet, spina bifida için epilepsi gibi)

Madde kötü kullanımı: erkek cinsiyet, kötü okul veya iş performansı, depresyon veya diğer psikiyatrik morbidite)

Bulantı, ağrının sol kola yayılması (özellikle orta üst kol)

Ailesel veya kişisel malign neoplazma öyküsü, geçirilmiş travma Arteriyel disseksiyon: yırtılma hissi, baş ağrısı, görme kaybı veya diğer nörolojik sekeller 


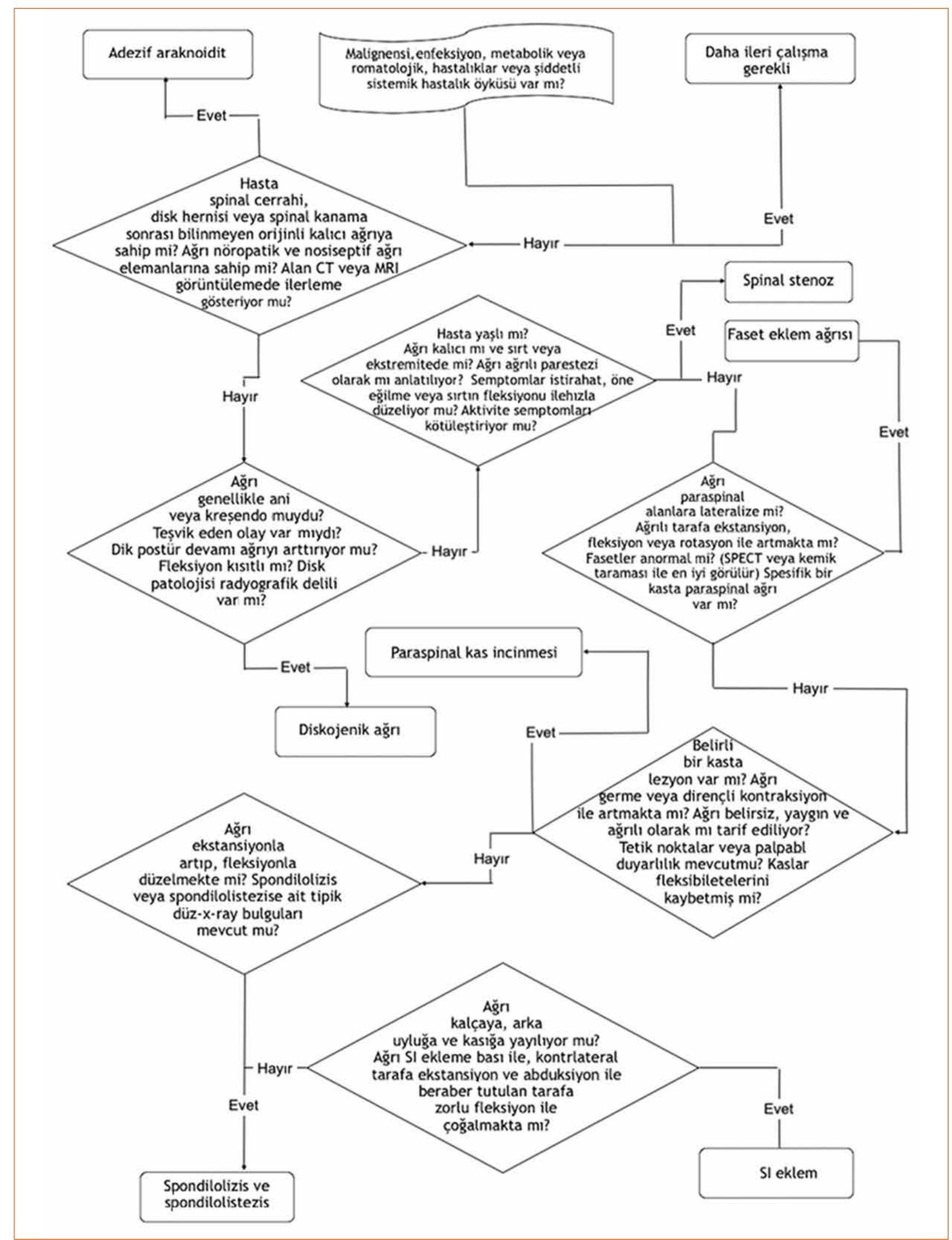

Şekil 1. Mekanik bel ağrısına yaklaşım. (Ross E'den değiştirilerek alınmıştır. $\left.{ }^{[7]}\right)$ 
sosyal hayatını kısıtlayacağı, tedavilerin yetersiz kalacağı şeklindeki beklentileri, ağrı seyrini ve tedavi başarısını olumsuz yönde etkilemektedir. ${ }^{[11]}$

\section{Ağrı ve fonksiyonel değerlendirme ölçekleri}

Ağrı tipinin ve karakterinin ortaya konulduğu bu süreçte, ağrının şiddeti ve algılanmasına, aynı zamanda oluşturduğu fonksiyonel bozukluk, özürlülük ve yetersizliğin tespit edilmesi ve yaşam kalitesinin belirlenmesine yönelik olarak, çeşitli ölçek veya skalalardan yararlanılmalıdır. Bu amaçla;

- Ağrı düzeyinin ölçümünde, tek maddeli Görsel Analog Skala (VAS), sayısal değerlendirme ölçekleri, McGill Ağrı Anketi (Kısa form - McGill Ağrı Anketi) veya Kısa Ağrı Envanteri;

- Nöropatik ağrı komponentinin anlaşılmasında, PainDETECT, LANSS skalası, S-LANSS, DN4 Anketi;

- Depresyon düzeyinin belirlenmesinde, Back Depresyon Ölçeği;

- Özürlülük düzeyinin tespitinde, Oswestry Özürlülük Sorgulama Formu, Roland Morris Özürlülük Skorlama Formu, Ağrı Özürlülük Indeksi;

- Yaşam kalitesinin belirlenmesinde, SF-36 (Kısa form 36) gibi çeşitli ölçekler ve sorgulama formları kullanılabilir. ${ }^{[12-18]}$

\section{Fizik Muayene}

Kapsamlı bir öyküyü takiben, ayrıntılı bir fizik muayene ile ağrı nedeninin büyük oranda ortaya konulması mümkün olabilmektedir. Sistemik muayeneyi takiben, bel ve boyun muayenesi bir düzen içinde yapılmalıdır. Postür analizi, bel ve boyun hareketlerinin değerlendirilmesi ve nörolojik muayenenin yanı sıra semptomları ortaya çıkaran özel provokatif test manevraları kullanılmalıdır. Bu sayı içerisinde KBBA'da muayene yöntemleri ayrı bir bölüm olarak anlatılacağından burada ayrıca değinilmeyecektir.

\section{Tanısal Testler}

Seçilmiş hastalarda düz grafiler, manyetik rezonans (MR) görüntüleme veya bilgisayarlı tomografi (BT), elektrodiagnostik testler (elektromiyografi/sinir iletim çalışmaları: EMG/SiÇ) ve kan testleri, tanıyı belirlemek için yararlıdır. Dejeneratif değişiklikler birden fazla düzeyde ortaya çıkabileceğinden, hastadaki semptom, nörolojik bulgular ve fizik muayene bulguları radyografik anomalilerle ilişkilendirilmelidir. Başlangıç tanısal çalışmalar için öneriler, Tablo 5'te topluca gösterilmiştir.

\section{Görüntüleme teknikleri}

Kronik bel ve boyun ağrılarında görüntüleme teknikleri için bilimsel kanıtlar ve kanıta dayalı tıp maalesef yetersiz kalmıştır. Ne zaman, hangi görüntülemenin istenip istenmemesi gerekliliği konusundaki tavsiyeler uzman görüşlerine dayanmaktadır. ${ }^{[19]}$ Ancak, genel görüş KBBA hastalarında da akut bel ağrılı hastalarda olduğu gibi, kırmızı bayraklar varlığında radyografik görüntülemeler (direkt filmler, MR veya BT taraması) endikedir.

Asemptomatik bireylerde $\% 75^{\prime}$ lere varan oranlarda radyolojik değişiklikler (annüler yırtık, Schmorl's nodülü, modic tipi değişiklikler vb.) olduğu gösterilmiş̧tir. [20] Diğer taraftan semptomatik hastaların çoğunda da benzer oranlarda görüntüleme bulgusu tespit edilememektedir. Bu nedenle, tanı ve tedavide karmaşa yaşanmaması için, endikasyon dışı radyolojik tetkik istenmemesine özen gösterilmelidir.

Düz radyografi: Yapısal ve dejeneratif omurga değişikliklerinin, iltihabi-neoplastik hastalıkların, fraktürlerin, dislokasyonların, dejeneratif eklem hastalıklarının, spondilolistezis ile vertebra tümörlerinin saptanmasında yardımcıdır. Bunun için standart ön-arka ve yan grafiler genellikle yeterlidir. Fleksiyon-ekstansiyon grafileri, cerrahi füzyon prosedürleri uygulanmış hastalarda, subluksasyon ve stabilite çalışmalarında yardımcıdır. Özellikle kadınlarda, radyasyon riskini önemli ölçüde arttırması ve gerçekte az miktarda ilave bilgi vermesi gibi nedenlerden ötürü, oblik grafilerin kullanılması önerilmemektedir.

MR veya BT: Kemik kanal morfolojisi ve yapısal/ konjenital vertebra anomalilerinin görüntülenmesinde, spinal stenoz, spondilozis ve spondilolistezis tanımlanmasında, fraktür varlığı veya şüphesinde, vertebral primer neoplazm ekartasyonunda, ayrıca MR görüntüleme yapılamıyorsa $\mathrm{BT}$ görüntüleme yapılabilir. Büyük oranda radyasyona maruz kalınması en büyük dezavantajıdır.

$M R$, yüksek doku çözünürlüğü sayesinde günümüzde altın standart görüntüleme yöntemi olmuştur. Kırmızı bayraklar varlığında, nörolojik defisit veya progresif nörolojik defisit söz konusuysa, şüpheli radikülopati veya miyelopatinin değerlendirilmesinde, disk hastalıkları ve hernilerinin görüntülenmesinde, ekstradural neoplazinin tanınmasında, eski ve yeni porotik kırıklar ile enfeksiyonların ayırımında, üstün tanı yeteneğine sahiptir. Çoğu durumda, kontrastsız bir MR görüntüleme yeterlidir. Kontrastlı MR ile enfeksiyon, tümör ya da cerrahi sonrası epidural fibrozis ayırımı kolaylıkla yapılabilir. En önemli avantajlarından birisi, radyasyon maruziyetinin olmamasıdır. 
Tablo 5. Kırmızı bayraklar ve başlangıç tanısal çalışmalar için öneriler

\begin{tabular}{|c|c|c|c|}
\hline Olası neden & $\begin{array}{l}\text { Öykü veya fizik muayenede } \\
\text { anahtar durumlar }\end{array}$ & Görüntüleme* & ilave çalışmalar* \\
\hline \multirow[t]{6}{*}{ Kanser } & Yeni başlayan LBP olan kanser öyküsü & MR & ESR \\
\hline & - Açıklanamayan kilo kaybı & Düz radyografi & \\
\hline & - Bir ay sonra iyileşme olmaması & & \\
\hline & - Yaş >50 yıl & & \\
\hline & Multipl risk faktörü mevcut & Düz radyografi veya MR & \\
\hline & & Kemik sintigrafisi & \\
\hline \multirow[t]{3}{*}{ Spinal kolon enfeksiyonu } & - Ateş & MR & BK \\
\hline & - İntravenöz ilaç kullanımı & & ESR ve/veya CRP \\
\hline & - Son zamanda enfeksiyon & & \\
\hline \multirow[t]{4}{*}{ Kauda ekina sendromu } & - Üriner retansiyon & MR & - \\
\hline & - Multipl düzeyde motor defisit & & \\
\hline & - Fekal inkontinans & & \\
\hline & - Eyer anestezisi & & \\
\hline \multirow[t]{3}{*}{ Vertebra kompresyon kırığı } & - Osteoporoz öyküsü & Düz radyografi & \\
\hline & - Kortikosteroid kullanımı & BT & - \\
\hline & - İleri yaş & & \\
\hline \multirow[t]{4}{*}{ Ankilozan spondilit } & $\begin{array}{l}\text { - Sabah sertliği } \\
\text { - Egzersizle iyileşme }\end{array}$ & $\begin{array}{l}\text { Ön-arka pelvis düz } \\
\text { radyografi }\end{array}$ & $\begin{array}{l}\text { ESR ve/veya CRP, } \\
\text { HLA-B27 }\end{array}$ \\
\hline & - Değişken kalça ağrısı & & \\
\hline & $\begin{array}{l}\text { - Gecenin ikinci yarısında sırt ağrısına bağlı } \\
\text { uyanma }\end{array}$ & & \\
\hline & - Genç yaş & & \\
\hline \multirow{4}{*}{$\begin{array}{l}\text { Sinir kompresyonu/bozuklukları } \\
\text { (örn; radikülopati olan disk } \\
\text { hernisi) } \\
\text { (Öneri 4) }\end{array}$} & $\begin{array}{l}\text { - L4, L5 veya S1 sinir kök yayılımında bacak } \\
\text { ağrısıyla beraber sırt ağrısı }\end{array}$ & - & - \\
\hline & $\begin{array}{l}\text { - Pozitif düz bacak kaldırma testi veya çapraz } \\
\text { düz bacak kaldırma testi }\end{array}$ & & \\
\hline & - Radikülopati semptom varlığı >1 ay & $\mathrm{MR}^{* *}$ & EMG/Siç \\
\hline & $\begin{array}{l}\text { - Şiddetli/progresif nörolojik defisit, şiddetli } \\
\text { motor zayıflık }\end{array}$ & & dikkate al \\
\hline \multirow{5}{*}{$\begin{array}{l}\text { Spinal stenoz } \\
\text { (Öneri 4) }\end{array}$} & - Yayılan bacak ağrısı & - & - \\
\hline & - İleri yaş & & \\
\hline & - Genellikle oturmayla rahatlayan ağrı & & \\
\hline & - Psödo-topallama (zayıf bir öngörücü) & & \\
\hline & Spinal stenoz semptom varlığı $>1$ ay & $\mathrm{MR}^{* *}$ & $\begin{array}{l}\text { EMG/Siç } \\
\text { dikkate al }\end{array}$ \\
\hline
\end{tabular}

* Tanısal değerlendirmede kanıt düzeyi değişkendir.

* Sadece hasta cerrahi veya epidural steroid enjeksiyonu için adaysa.

ESH, eritrosit sedimentasyon hızı; MR, manyetik rezonans; BT, bilgisayarlı tomografi; EMG, elektromiyelografi; SiÇ, sinir iletim çalışmaları. 


\section{Elektrodiagnostik testler (elektromiyografi / sinir ileti çalışmaları: $E M G / S i C ̧)$}

Görüntüleme ve klinik bulgular tam çakışmadığı zaman ya da radikülopatiyi taklit eden periferik nöropati veya sinir tuzaklanmalarından şüphelenildiğinde, elektrodiagnostik testlere başvurulmalıdır. Radikülopatiyi ortaya koymada, etkilenen kök seviyesini, etkilenim süresi ve şiddetini belirlemede, elektrodiagnostik incelemeler yardımcıdır. Spinal kök lezyonunun proksimal kök lezyonundan ya da nöropatinin radikülopatiden ayırt edilmesi mümkündür. Radikülopatili hastalarda klinik yakınma ve bulgular duyusal liflerin etkilendiğini düşündürse de, duyusal sinir aksiyon potansiyelleri (DSAP) ve ileti hızları radikülopatide normaldir.

\section{Laboratuvar testleri}

Bireysel hasta öyküsü ve incelemeye dayanarak, romatolojik, enfeksiyöz veya onkolojik, non-spinal nedenlerden şüphelenildiğinde, ayrıca çok yaşlı hastalarda laboratuvar tetkikleri istenmelidir. Beyaz küre sayımı, eritrosit sedimentasyon hızı, C-reaktif protein tanıda önemlidir. Servikal radikülopati, stenoz, miyelopati, diskojenik ağrı ve faset sendromu gibi boyun ağrısının dejeneratif nedenlerinde, eritrosit sedimentasyon hızı ve C-reaktif protein gibi inflamasyonun serolojik belirteçleri normal olmalıdır. Bununla birlikte, polimiyalji romatika, romatoid artrit veya septik diskit gibi enfeksiyöz durumlarda, eritrosit sedimentasyon hızı ve C-reaktif protein artabilir.

\section{SONUÇ}

Kronik bel ve boyun ağrıları, biyo-psikososyal faktörler arasında karmaşık etkileşimlerle karakterize bir hastalıktır. Çok boyutlu doğası gereği KBBA'nın değerlendirilmesi ve yönetimi de, organik patolojiye odaklı biyomedikal yaklaşımların ötesinde, çok eksenli ve interdisipliner bir yaklaşım gerektirmektedir. Kapsamlı bir sorgulama ve fizik muayeneyi takiben, gerekli durumlarda laboratuvar tetkikleri ve görüntüleme yöntemlerinden yararlanılarak, ağrının nedeninin ortaya konulmasına yönelik yapılan biyomedikal yaklaşımlara ilave olarak, sosyal, duygusal, bilişsel, çevresel ve davranışsal faktörlerin ortaya çıkarılmasını sağlayacak, standart değerlendirme araçlarından da yararlanılmalıdır.

\section{KAYNAKLAR}

1. Cassidy JD, Carroll LJ, Côté P. The Saskatchewan health and back pain survey. The prevalence of low back pain and related disability in Saskatchewan adults. Spine (Phila Pa 1976) 1998;23(17):1860-6.

2. Cote P, Cassidy JD, Carroll L. The Saskatchewan Health and Back Pain Survey: the prevalence of neck pain and related disability in Saskatchewan adults. Spine 1998;23(15):1689-98.

3. Webb R, Brammah T, Lunt M, Urwin M, Allison T, Symmons D. Prevalence and predictors of intense, chronic, and disabling neck and back in the UK general population. Spine 2003;28(11):1195-202.

4. Kang JH, Chen HS, Chen SC, Jaw FS. Disability in patients with chcronic neck pain: heart rate variability analysis and cluster analysis. Clin J Pain 2012;28(9):797-803. Crossref

5. Erken HY. Bel ağrısı tanı ve tedavisinde kırmızı ve mavi bayraklar. TOTBID dergisi 2015;14:252-57. Crossref

6. Cohen SP. Epidemiology, diagnosis, and treatment neck pain. Mayo Clin Proc 2015;90(2):284-99. Crossref

7. Ross E. Back pain. In: Von Roenn JH, Paice JA, Preodor ME, editors. Current diagnosis and treatment of pain. USA: The McGraw-Hill Companies; 2006. p.172-209.

8. Heitz CA, Hilfiker R, Bachmann LM, Joronen H, Lorenz $\mathrm{T}$, Uebelhart D, Klipstein A, Brunner F. Comparison of risk factors predicting return to work between patients with subacute and chronic non-specific low back pain: systematic review. Eur Spine J 2009;18(12):1829-35. Crossref

9. Dansie EJ, Turk DC. Assessment of patients with chronic pain. Br J Anaesth 2013;111(1):19-25. Crossref

10. Bair MJ, Robinson RL, Katon W, Kroenke K. Depression and pain comorbidity: a literature review. Arch Intern Med 2003;163(20):2433-45.

11. Quartana PJ, Campbell CM, Edwards RR. Pain catastrophizing: a critical review. Expert Rev Eurother 2009;9(5):745-58. Crossref

12. Kuğuoğlu S, Aslan F, Olgun N. Mc Gill Melzack Ağrı Soru Formu (MASF)'ın Türkçeye uyarlanması. Ağrı 2003;15(1):47-52.

13. Freynhagen $\mathrm{R}$, Baron $\mathrm{R}$, Gockel $U$, Tölle TR. painDETECT: a new screening questionnaire to identify neuropathic components in patients with back pain. Curr Med Res Opin 2006;22(10):1911-20.

14. Bennett M. The LANSS Pain Scale: the Leeds assessment of neuropathic symptoms and signs. Pain 2001;92(1-2):147-57.

15. Beck AT, Ward CH, Mendelson M, Mock J, Erbaugh J. An inventory for measuring depression. Arch Gen Psychiatry 1961;4:561-71

16. Fairbank JC, Pynsent PB. The Oswestry Disability Index. Spine (Phila Pa 1976) 2000;25(22):2940-52.

17. Küçükdeveci AA, Tennant $A$, Elhan $A H$, Niyazoglu $H$. Validation of the Turkish version of the Roland Morris Disability Questionnaire for use in low back pain. Spine (Phila Pa 1976) 2001;26(24):2738-43.

18. Ware JE Jr, Gandek B. Overview of the SF-36 Health Survey and the International Quality of Life Assessment (IQOLA) Project. J Clin Epidemiol 1998;51(11):903-12.

19. Mazzola Eusébio O, Motamed S. Imaging indication for low back pain in the adult population. Rev Med Suisse 2013;25;9(399):1732-6.

20. JarvikJG, Deyo RA. Diagnostic evaluation oflow back pain with emphasis on imaging. Ann Intern Med 2002;137(7):586-97. 